\title{
Neo-Kantian Theories of Self-Determination: A Critique ${ }^{1}$
}

David Miller

Nuffield College, University of Oxford

Oxford OX1 1NF

Email: david.miller@nuffield.ox.ac.uk

\section{Biographical note}

I am Professor of Political Theory, University of Oxford, and an Official Fellow of Nuffield College. I have worked extensively on questions of social and global justice, on nationality and citizenship, and on problems in democratic theory. My current research focuses on human rights, territory and immigration. My three most recent books are National Responsibility and Global Justice (OUP, 2007), Justice for Earthlings (CUP, 2013) and Strangers in Our Midst (Harvard UP, 2016). Among relevant recent articles are 'Democracy's Domain', Philosophy and Public Affairs, 2009, 'Territorial Rights: Concept and Justification', Political Studies, 2012, and 'Debatable Lands', International Theory, 2014.

\section{Abstract}

Neo-Kantian political theories, such as those developed by Jeremy Waldron and Anna Stilz, aim to provide an account of state legitimacy and territorial boundaries that avoids the problems faced by rival nationalist theories. Kant's own theory of the state appears to be biased towards the status quo, and therefore has difficulty in explaining what is wrong with rights-respecting colonialism or the annexation of one state by another. Two possible ways forward are explored. One involves making state legitimacy conditional on meeting more stringent standards of distributive justice. The other involves appealing to the idea of a self-determining 'people'. However the latter must avoid collapsing either into a version of nationalism (if the 'people' are identified in cultural terms) or a form of voluntarism (if the 'people' are required subjectively to 'affirm' the regime that governs them). Thus neo-Kantian theories cannot deliver a plausible account of self-determination without, like Kant himself, tacitly invoking political identities of the kind that they seek to repudiate.

Keywords: self-determination, legitimacy, territory, colonialism, Stilz, Waldron

\section{Introduction}


In this article, I examine critically some recent attempts to develop theories of political selfdetermination that draw their inspiration from Kant's political philosophy. The value of selfdetermination itself - of a people being able to decide which laws to impose on itself and which other policies to pursue, free from outside domination - is taken for granted here. Instead the questions I shall pursue concern the identity of the 'self' in self-determination what qualifies a set of individuals to be a 'people' with a right to political autonomy - and about the territorial claim that accompanies this, since political self-determination requires jurisdiction over a defined geographic space. ${ }^{2}$ These two questions are closely connected, and indeed one way of answering the first, as we shall later see, is to give a purely territorial definition of a 'people' as all and only those individuals who occupy a particular portion of the earth's surface. But initially it is better to keep them apart, and treat 'who are the people?' and 'what territory can they rightfully claim?' as questions each needing an independent answer.

At this point someone might interject that the questions in the previous paragraph are badly posed because the entities entitled to self-determination are states not peoples, and it is not difficult to identify something as a state, and to determine what territory it is entitled to control. But although it is indeed possible to propose a purely statist theory of selfdetermination, it seems, on the one hand, hard to understand why self-determination should be valuable if its possessor is merely an institution with a monopoly of coercive force, and on the other hand, hard to square such a theory with certain of our firmly held political beliefs. In particular, we want to be able to explain what is wrong about colonialism, understood as an arrangement whereby one group of people rules another either proximately or at a distance, and the obvious answer is that the wrong of colonialism 
lies at least partly in the ruled-over group being denied political self-determination. ${ }^{3}$ We also want to explain what is wrong about involuntary annexation, whereby one state simply absorbs part of the territory that previously belonged to another and governs it as its own. And, reversing the example, we are likely to want to say that there are cases in which a territorially-concentrated group has a valid claim to secession from an existing state. It will be difficult for a purely statist theory of self-determination to handle these examples satisfactorily. Of course, one might bite the bullet in each case, and say, for example, that the wrongs of colonialism were contingent and not inherent in the very nature of colonial rule. But I suspect that most readers will believe that colonialism and involuntary annexation are intrinsically unjust, and secession sometimes just, and holding these beliefs reveals that we value the self-determination of peoples, defined in some other way than as collective subjects of the states that at any moment govern them.

The theories of self-determination that I shall explore accept the challenge posed in the last paragraph, and aim to show that Kant's theory of the state can be developed in a way that gives us a theory of self-determination strong enough to explain the wrongness of colonialism and annexation (and thereby at least to justify secession by the colonized and the wrongfully annexed). ${ }^{4}$ But they also aim to do so in a way that avoids what they regard as the dangers and pitfalls of rival nationalist theories. In theories of the latter kind, the 'self' in 'self-determination' is the nation: a body of people who identify with one another on the basis of shared cultural values and symbols, a history of living together, normally on the territory they regard as their home, and who value their association. The strengths of nationalist theories are fairly obvious. First, since the idea of self-determination only makes sense if there is a collective agent to do the determining, the nation looks like a plausible 
candidate to fill this role. The people who belong to it share a collective identity that enables them to see what is done in their name as something that they have helped to coauthor. Second, if as seems plausible self-determination in its strongest form requires democratic government, and if democratic government in turn requires a sufficient level of trust and solidarity that people are willing to accept and comply with decisions that they personally disagree with, then nationhood provides the cement that enables democracy to work effectively. Third, nationality provides a solution to the territorial question. The land that the nation has occupied and developed historically is the land over which it can now claim to exercise jurisdiction.

There are, however, problems with each of these claims, which together have prompted neo-Kantians and others to develop theories of self-determination that do not make any reference to cultural nations as understood in the previous paragraph. There is first of all the problem of deciding, in a non-arbitrary way, which groups of people should count as nations and which do not. Are the Kurds a nation, for example, or are they merely an ethnic group distributed across four nations? What should we say about national minorities such as the Welsh or the Catalans? Do they qualify as nations for purposes of selfdetermination? Then there is the problem that nations represent themselves as internally homogenous, ignoring the presence within their physical boundaries of groups (such as recent immigrants) who do not identify themselves culturally with the nation itself. Thus if the 'self' in self-determination is understood to be the national self, these groups are inevitably excluded. Moreover they are being designated as co-authors of policies to which they may be deeply opposed. And finally, even if an appeal to the nation's history can serve to identify a national 'heartland', there are very likely to be contests with neighbouring 
nations over borderlands or enclaves to which each has some more or less plausible claim. Thus far from solving the territorial question, an appeal to nationality may inflame it by turning boundary disputes into matters of national pride and humiliation.

I do not mean to suggest that these problems are insoluble - indeed in other writing I have suggested some solutions. ${ }^{5}$ But they are serious enough to motivate the search for an alternative theory of self-determination that avoids them. This explains the appeal of neoKantian theories which explain the identity of a 'people' in political rather than cultural terms, as a group whose members stand in a certain kind of relationship to one another, paradigmatically (though not always) as citizens of a legitimate state. I call these theories neo-Kantian because they take as their starting point Kant's account of political legitimacy and the implicit theory of territory that goes with it. However they develop Kant's theory in such a way that it becomes more democratic, and in doing so they also seek to make it less biased towards the status quo - more likely to support changes of regime such as those that occur in decolonization or secession, at least under favourable circumstances. A key question, then, is whether this can be done without surreptitiously introducing elements that do not belong within a theory that aims to remain faithful to its Kantian roots. In particular, a neo-Kantian theory must avoid importing cultural assumptions of the kind to which its nationalist rival appeals. I shall begin, therefore, with a brief sketch of Kant's own theory of the state, asking how well it can answers questions about the proper scope of selfdetermination. I then explore two ways in which neo-Kantians have sought to extend that theory, one of which involves importing a stronger account of distributive justice as a condition of state legitimacy, and the other of which strengthens the requirement that the state should be sufficiently representative of the people who it governs. I argue that neither 
of these strategies is successful. Neo-Kantians are left with an unpalatable choice. If they want to move beyond a purely statist account of self-determination - which they need to do in order to explain what's wrong with colonialism and annexation - they have implicitly to adopt either a nationalist or a voluntarist account of self-determination. I conclude by arguing that, insofar as neo-Kantians want to be democrats, they should concede that the 'self' in self-determination must be culturally as well as politically unified. In other words, they must be prepared to make some concessions to nationalism.

\section{Kant's theory of the state and self-determination}

The main elements of Kant's theory of the state are fairly familiar, so I will present them only briefly. ${ }^{6}$ He begins by considering a hypothetical state of nature in which people have provisional claims to the objects they have taken into their possession, but no effective obligation to respect the possessions of others. Because of the instability and insecurity of such a condition, Kant argues, people who live in close proximity to one another, and therefore cannot avoid interacting, are morally obliged to enter the civil condition and acknowledge a political authority whose coercive law can guarantee their property rights. There is no choice about this, so anyone meeting the proximity condition can be compelled by others to join the state if he refuses. The state's territorial rights correspond to the area occupied by the people over whom it exercises jurisdiction. The justification for its exercise of those rights is simply that it thereby replaces 'a state devoid of justice' with 'a rightful condition'. ${ }^{7}$

It is important to underline here that for Kant, unlike say Locke, consent plays no part in this account of political legitimacy. ${ }^{8}$ Anyone can compel others with whom he unavoidably interacts to place themselves under the authority of the state. 'If it must be possible, in 
terms of rights, to have an external object as one's own, the subject must also be permitted to constrain everyone else with whom he comes into conflict about whether an external object is his or another's to enter along with him into a civil constitution. ${ }^{9}$ One corollary of this is that, for Kant, the actual historical process whereby states were formed and their boundaries were established is morally irrelevant. Given that we cannot help interacting with our fellow-citizens in the state to which we belong, we remain under an obligation to uphold the prevailing constitution so long as it meets general criteria of legitimacy. This explains why Jeremy Waldron, who follows Kant here, is justified in labelling his view a 'territorial theory of self-determination'. ${ }^{10}$ The group who form the self that is capable of being self-determining are territorially defined: they are those who fall under the jurisdiction of a state whose authority they are bound to uphold, for Kantian reasons.

The question, however, is whether such a purely territorial theory can withstand critical scrutiny. Kant tells us that we are bound to enter into a political relationship with those we 'cannot avoid living side by side with'. There is a hypothetical world in which this criterion might yield a determinate answer to the self-determination question, one in which human beings found themselves already grouped into distinct communities whose members unavoidably interacted quite intensively with each other, but in which interactions across communities were relatively rare - for instance a world composed of small islands each capable of supporting human life but separated by wide expanses of sea. In such a world there would be no question about the identity of the people with whom one was required to enter into a civil relationship. But in general our world is not like that: human populations and their economies are naturally continuous with one another, and where this is currently not the case, it is likely to be the result rather than the cause of political 
boundary-drawing. Thus the political relationships that Kant wishes to endorse are arbitrarily constituted, and Kant can give no answer to someone who asks why they should be morally required to enter or remain in the civil condition with this group of people rather than with some alternative group, other than by saying that this is a question one is not permitted to ask. The persuasive reasons he advances for a (coercively enforceable) obligation on the part of each individual to enter a legitimate state do not explain who should be included in its jurisdiction or where its territorial boundaries should be set. Kant also has to explain why the state's jurisdiction should not be universal - why there should not be a single world state. There is, after all, likely to be some interaction between people across state boundaries wherever these are drawn. Moreover the moral reason that Kant advances for the obligation to enter the civil condition - that taking possession of any external object would be a unilateral restriction of the freedom of others until possession is converted into property under a law that applies to all - might seem to apply reiteratively to the state's claim to jurisdiction over territory, which if successful renders that territory unavailable for others to use. Kant appears to acknowledge in response that states are in turn morally obliged to enter into a 'rightful' relation with one another, but Kant scholars disagree about the exact nature of this requirement. ${ }^{11}$ He speaks of independent states forming a 'league' or sometimes a 'federation' in order peacefully to settle disputes that might arise between them, but it is not easy to pin down what Kant had in mind - in particular whether membership of the association must always remain voluntary, or whether it could be compelled. ${ }^{12}$

There is no need here to delve into the precise nature of Kant's alleged cosmopolitanism. Suffice it to say that he ends with a clear rejection of proposals for a global state, partly on 
the grounds that it would become 'that universal despotism which saps all men's energies and ends in the graveyard of freedom ${ }^{13}$, and partly because he believes that republics should only be of moderate size since 'the laws progressively lose their impact as the government increases its range'. ${ }^{14}$ What is of greater interest here are the reasons he gives for thinking that the arrival of world government is in any case unlikely. He took for granted the existence of distinct nations, each with its own discernible character, and this diversity especially of language and religion - could, he claimed, be seen as nature's way of keeping people apart and preventing the emergence of a single dominant world power. ${ }^{15}$ But here Kant is introducing cultural elements of precisely the kind that the neo-Kantians want to exclude from their accounts of political legitimacy and self-determination. If state formation is determined by tribal or national identities and the unwillingness of people to join together with those they regard as culturally different from themselves, then we no longer find the sharp contrast that neo-Kantians want to draw between their own account of self-determination and the rival nationalist theory.

Suppose, then, we were to set these remarks aside as an aberration on Kant's part. Does it really matter that Kant has nothing to say about the basis on which states should be formed, other than that they should not be so tiny that they are unable to internalise most of the property disputes that their members are likely to be involved in, or so vast that the legal system becomes unwieldy and ineffective? In between there are many ways in which the world might be divided into states of different sizes, and the moral imperative that Kant lays upon us to establish a civil constitution cannot guide us in deciding where and with whom that constitution should be enacted. But perhaps the lesson we are supposed to draw is that where legitimate states exist, we are morally obliged to support them, including 
supporting their current boundaries. That things might have been arranged differently is of no concern. The 'self' in 'self-determination' is simply the group of people who, as a matter of historical chance, now find themselves sharing citizenship in a legitimate state. That some of them might wish to reconstitute the self along different lines is irrelevant. Given that the existing state protects human freedom, which depends only upon its internal constitution, there is a moral requirement to uphold the civil condition that trumps any preferences a sub-group might have to secede and establish an independent state of their own, or to affiliate with a neighbouring state. And recall that this is not because they have voluntarily entered into a social contract which, it might be thought, they are not now entitled to break. Historically, they may have been incorporated into the state by force.

Such a statist reading of Kant's theory would however fail to do justice to the positions he himself adopts on colonialism and on the annexation of one state by a second. In the case of colonialism, he came in his later writings to revise his previously favourable assessment of European colonialism. ${ }^{16}$ Admittedly Kant's position here requires some teasing out from remarks made in passing. He has harsh things to say about the actual practice of colonial ventures carried out by European states for commercial reasons. ${ }^{17}$ But he comments only briefly on the colonial relationship as such - the subordination of one state to the rule of another - in the context of a discussion of the aftermath of war. ${ }^{18}$ Here he seems to envisages colonies as retaining their own constitution and power to legislate internally, but having their external relations with other states controlled by the colonial master which holds 'supreme executive authority'. This involves a loss of political autonomy, though not necessarily of individual freedom under the law. That Kant regards this status as undesirable is not in question, since he presents it as a fate that a victorious state is not 
allowed to impose on the vanquished, but the grounds on which he does so remain unclear - always bearing in mind that for Kant a legitimate state need not be democratically constituted: it can have 'passive' as well as 'active' citizens ${ }^{19}$.

Kant also addressed the European practice that allowed monarchs to bequeath their realms to one another. He held that it was impermissible for an independent state to be acquired by another 'by inheritance, exchange, purchase or gift'. He argued that:

..a state, unlike the ground on which it is based, is not a possession (patrimonium). It is a society of men, which no-one other than itself can command or dispose of. Like a tree, it has its own roots, and to graft it on to another state as if it were a shoot is to terminate its existence as a moral personality and make it into a commodity. ${ }^{20}$

These remarks would seem to apply more generally to cases where one state annexes a second, even if the annexing state then proceeds to grant citizenship rights to the annexees. The key phrase is 'terminate its existence as a moral personality'. Kant's thought seems to be that once a state has come into existence it acquires a moral identity of its own, and to deny this by acquisition is to wrong the people whose state it was, even if as individuals they are subsequently treated fairly by the acquiring state.

But how, more precisely, is this thought to be spelt out? What does it mean to say that an established state has a 'moral personality' of its own that would be annihilated by its being incorporated into a larger unit? As we have seen Kant himself tended to think of 'peoples' as nations with distinct characters. And he resisted the suggestion that their distinctness could be explained as the product of different political regimes. As he put it in his lectures on anthropology, 'to claim that the kind of character a people will have depends entirely on 
its form of government is an ungrounded assertion that explains nothing: for from where does the government itself get its particular character?'. ${ }^{21}$ So it seems that for Kant, claims to political self-determination were indeed connected to the fact that each political community embodies a 'people' with its own set of cultural values and character traits, and this is what is denied expression when one state subordinates another, whether by absorbing it internally or ruling it from afar. But this brings him closer to the nationalist theory of self-determination that neo-Kantians are determined to avoid.

\section{Neo-Kantian theory: the appeal to justice}

So how might a neo-Kantian explain the wrongness of colonialism or involuntary annexation without appealing to cultural grounds for self-determination? Suppose we begin with a conception of 'a people' that refers simply to the collection of persons who live and interact with one another on a given area of land. According to Waldron 'the territorial version of the self-determination principle holds that the people of each territory have a right to work out their own constitutional, political, and legal arrangements without interference from the outside'. And he immediately goes on to say that this rules out cases such as Mozambique being ruled by the Portuguese, Ireland being ruled by the United Kingdom, or Palestine being ruled by the Ottoman Empire as violations of the principle. ${ }^{22}$ But this argument assumes that we have already been able to individuate 'peoples' on a territorial basis. It assumes that we know that 'Mozambique' forms a separate territory, and is not merely a district of Portugal governed from Lisbon like the other districts. Recall that we cannot make this judgement on the grounds that the Mozambicans are culturally distinct from the Portuguese, if we are to remain faithful to the neo-Kantian injunction to ignore culture as a basis of political identity. We cannot just assume that the Mozambicans form a separate 
people: we have to be able to explain why this is so. ${ }^{23}$ If we look at Waldron's examples of colonized peoples, they amalgamate two features: geographic separation from the metropolis and non-democratic governance. Or to be more precise, the example of Mozambique displays both features, whereas the example of Ireland displays only the first (since Irish constituencies sent representatives to the Westminster Parliament during the period Waldron has in mind) and the example of Palestine displays only the second (since the Ottoman empire covered a continuous tract of land from the Balkans to North Africa with Palestine somewhere in the middle). So we need to ask what significance geographic separation and non-democratic governance can hold for neo-Kantians.

Clearly the presence or absence of democratic governance is relevant to any theory of selfdetermination. If a neo-Kantian were to assume that any self-determining people must be democratically governed, then the Ottoman and Portuguese Empires failed this test, and it would seem to follow straightforwardly that the Mozambicans and the Palestinians were entitled to secede and to create legitimate states for themselves. ${ }^{24}$ Whether a neo-Kantian would want to make such a strong assumption is more moot. ${ }^{25}$ It would follow that any group currently residing on the territory of a non-democratic state had a similar right to secede, regardless of how well the state was performing in other respects. This takes the theory some distance away from its Kantian roots, where legitimacy is closely tied to the state's provision of a legal regime that protects persons and property. I return later to the way in which neo-Kantian theories, in their effort to avoid statism, might collapse into a form of voluntarism. But here I want to focus on geographic separation. Why might this be relevant ${ }^{26}$ In the case of the British and the Irish, a neo-Kantian might point out that the existence of the Irish Sea means that they do not unavoidably have to live side by side with 
each other. So they would not be obliged to create a single encompassing state originally. On the other hand, once a single state has been created, it is far from clear that, on Kantian grounds, the possibility of separate existence and limited interaction creates a permission on the part of a sub-group to secede. So to show conclusively that the United Kingdom in the form that it existed prior to 1922 (i.e. including the whole of Ireland) fails the neoKantian test, one would need to point to some defect in its constitution that means it could not be presented as a genuine case of self-determination for everyone including its Irish citizens. The fact that Ireland was represented in Westminster by only a small minority of MPs (105 out of 707 in 1918, for example) cannot be sufficient, since the same could be said of any region of England.

How might a neo-Kantian theory try to show that the Irish in 1922 had a valid claim to selfdetermination that was not met by their incorporation into the Westminster parliament? I see two possible ways forward. One involves an appeal to distributive justice, and maintains that states that inflict what Buchanan calls 'serious and persistent injustices' on some of their members lose their legitimacy and create self-determination claims on part of the unjustly treated group or groups. ${ }^{27}$ This proposal might be thought to apply to the Irish case: although Irish citizens were formally represented at Westminster following the Acts of Union of 1800, there is little question that the policies pursued in Ireland by the British government during the $19^{\text {th }}$ century were severely unjust - at their worst producing mass starvation. So the suggestion here is that a group that suffers serious injustice within an otherwise legitimate state has a right to secede and become an independent state.

But what criterion of justice should be used to make this judgement? In Buchanan's more recent account there are three circumstances of secession-justifying injustice: 1 ) large-scale 
and persistent violations of basic individual human rights; 2 ) unjust taking of a legitimate state's territory; 3 ) serious and persistent violations of intrastate autonomy agreements. ${ }^{28}$ He also considers, but does not finally endorse, two other circumstances: a group that finds itself in a permanent minority on 'fundamental issues of value', and 'discriminatory redistribution', i.e. the state using its power over resources systematically to advantage one group at the expense of another. ${ }^{29}$ Although he concedes that group-directed social injustice of these kinds might give a minority group the moral right to attempt to secede, he is reluctant to widen the grounds under which secession can be claimed as a legal right under international law. And the reason he gives is that the claims advanced under this heading are likely to be contentious. There are no agreed international standards of distributive justice that could be appealed in order to settle whether a state is currently engaged in discriminatory redistribution. And equally there will be no agreement on what qualifies as a fundamental issue of value: 'proposals for what counts as an objective standard of importance are likely to be hotly disputed and it seems equally wrong to allow what counts as fundamental to be decided by the majority or by the minority'. ${ }^{30}$ Since Buchanan's second and third criteria of injustice - wrongful taking of territory and violation of autonomy agreements - look back to events in the past, social injustice by itself will create a right to secede on the part of the unjustly treated group only when they can show that their human rights are being persistently violated. It is doubtful whether Irish republicans in, say, 1916 could have made this claim. ${ }^{31}$

It would of course be possible to move further in the direction suggested by Buchanan, and propose that any serious distributive injustice perpetrated by the state would give the group suffering from the injustice the right to secede. But this would mean moving further away 
from the original Kantian theory of legitimacy in a direction that neo-Kantians are unlikely to applaud. Recall that for Kant, a state is legitimate when it establishes a legal system that can successfully resolve the disputes over property and so forth that would arise in a hypothetical state of nature. It is not required to implement any particular theory of distributive justice. Kant's followers are quick to point out that such theories are a subject of controversy. The point of having a coercively enforced legal system is that it can resolve disagreements between people who live in close proximity to each other, including disagreements that arise because people hold different views about what justice requires. As Waldron puts it, 'Kant's view is that people who find themselves quarrelling over the just use of resources are required, morally, to enter into political community with one another, so that their disputes can be resolved consistently within a single coherent framework of laws'. ${ }^{32}$ This aim would be defeated if a group that believes that it is not receiving its fair share of the state's resources is justified for that reason alone in seceding and taking the resources it claims. My point here is not that a justice-based theory of secession and selfdetermination is incoherent or impossible to formulate: the point, rather, is that it departs radically from an account of self-determination that takes the 'self' to be a territorially concentrated group who for Kantian reasons are obliged to form a political community. So such a theory would not be 'neo-Kantian' any more than, say, a voluntarist theory that requires individual consent to join on the part of all those who are going to form the self. ${ }^{33}$ Thus we are left with the problem of explaining why, for neo-Kantians, a self-determination claim can be lodged against an imperial state that upholds an effective legal system in the society that it rules, or an annexing state that does likewise. Waldron poses the question himself: 'why is it important that all this be sorted out by the very people among whom the 
thicket of potential disputes arises? Why wouldn't the imposition of a legal framework by an imperial power solve this problem?'. But his reply is a little mysterious: 'It would, but not in a respectful way, not in a way that respected the fact that the people themselves among whom these disputes may arise may have a perspective on their solution. ${ }^{34}$ Recall that there is no assumption here that 'the people' are held together by cultural ties: they need not in any sense be a 'nation'. So what is this perspective that they are supposed to share, simply in virtue of their physical proximity and without assuming agreement on questions of distributive justice, for instance? They might be able to create a political framework that would allow them to take decisions, but this might also mean a majority group imposing its will on a minority, say if the emergent state is sharply divided along lines of religion or ethnicity. The problem for Waldron then is to explain why an arrangement that allows the local majority to dominate a minority is more respectful than the form of imperial rule that preceded it, if both meet the general Kantian requirements for legitimacy. ${ }^{35}$

\section{Neo-Kantian theory: the appeal to political co-operation}

I said earlier that there were two possible ways forward for a neo-Kantian attempting to show that valid self-determination claims could be lodged against a dominating external power. The first path, involving an appeal to distributive justice, seems unpromising. The second path picks up Kant's comment about the 'moral personality' of the state, and argues that rule from the outside denies this. This is the approach favoured by Stilz. She begins with what is perhaps the easiest case, where one democratic state forcibly absorbs another (for example, the US decides to annex Canada). This would be objectionable, she thinks, because the people of Canada will have worked together over time to develop their own particular institutions 'in accordance with their principles and priorities'. 
For that reason, the forcible merger of democratic states disrespects the collective autonomy of citizens. Even though they did not choose their compatriots, if their state is a legitimate one, they will have freely engaged in shaping their terms of citizenship, and the laws to which they are subject will reflect the history of that interaction. Thus, while the boundaries of 'the people' are historically contingent and unchosen, 'peoples' may still exist today - having been brought into being by states and will reflect forms of political cooperation that we have reason to respect. ${ }^{36}$

The underlying idea here is that self-determination is not something that happens from moment to moment but develops over time as citizens together enact laws and policies that then provide the context in which future laws and policies will be chosen, so continuity is important. If one has been engaging together with fellow-Canadians up to now to take decisions that reflect the principles and priorities that have emerged in this group, it is not acceptable to be told that from this point on the relevant collective will include a majority of Americans with (presumably) somewhat different priorities and principles. ${ }^{37}$

Stilz's position favours groups who now have, or have recently had, states of their own: it is living together under the auspices of a state that makes individual persons into 'a people' who then have a claim either to continue to be self-determining or to have their opportunity for self-determination restored as the case may be. But why, one might ask, should these groups be privileged over other groups that might have been partially self-determining long ago, or perhaps never even had the chance to be, but nonetheless retain a sense of their own distinct identity and could practice self-determination if they were allowed to? These groups too may find that they have principles and priorities that are somewhat different from those of the majority in the larger state of which they now form a part, and they may 
have little success in getting their preferences translated into law and policy. So why do they not have a right to some form of self-determination?

One answer might be that there is no ongoing practice of self-determination that is being disrupted. But clearly self-determination cannot only be valuable where it already exists, otherwise there would be no reason to begin it. Perhaps it is worse to destroy an existing scheme of political cooperation than to prevent one from starting up, but assuming that the proposed scheme is feasible and its participants want to initiate it, there must be some reason to allow it to begin. ${ }^{38}$ Another possibility is that the groups we are considering do not count as 'peoples' because they have not been 'brought into existence by states'. But here we need to ask what is special about political groups that have been formed in the bosom of states. Why do they have preferential status as subjects of self-determination?

Stilz's answer seems to be that they have worked together over time to create a political and legal system. This is certainly an achievement, particularly if we keep in mind Waldron's rather pessimistic view that 'we form political community with those with whom [we] are likely to fight, rather than with those whom we already like and who are, in their identity, already like us. Law's function, on this conflict-and-process oriented model, is to keep the peace and provide for cooperation among people who are not well disposed to one another already'. ${ }^{39}$ Peoples formed by existing states have overcome the Hobbesian war of all against all and found a way to live together under the rule of law. Now other groups may also have practised forms of political cooperation even if they have not had states of their own. Liberation movements, for example, require their members to set aside their differences, make compromises, and work together in the common struggle. But it might be argued that this is less demanding than what is required to maintain statehood over time. 
In some cases there may be real doubt as to whether the members of a group aspiring to self-determination will in fact be able to work together in such a way as to sustain an independent state. This has been said about the Kurds, for instance, speaking different dialects and currently distributed across four separate states. But in other cases it would be far-fetched to assume that the necessary co-operative capacity will not be forthcoming. If we consider any of the minority nations in democratic states with significant secessionist movements - the Quebecois, the Catalans, the Scots and so forth - their members are long schooled in habits of co-operation, both with each other and with the larger society to which they belong. Whatever one thinks about the validity of their claims to selfdetermination, no one could seriously suggest that an independent Quebec or Catalonia or Scotland would immediately collapse into infighting. It no doubt helps that these peoples already have experience of independent political co-operation through forms of partial autonomy. This takes us back to the question of why states are supposed to be special as sites of political cooperation, such that only 'peoples' who have been formed within them have valid self-determination claims.

So far the answers we have unearthed are less than decisive. It's arguably worse to interrupt an ongoing practice of self-determination than to prevent a new one from starting up; and whereas we know that state-formed peoples have mastered the art of political cooperation, there may be uncertainty about whether prospective peoples can do the same. But there's also a third possible answer, which involves revisiting the connection between self-determination and territory. Assuming, as we have throughout, that self-determination must be territorial in nature, since it involves making law and policy across a defined geographical jurisdiction, it may appear that only state-formed peoples come equipped with 
the necessary territorial rights. This follows from the (Kantian and neo-Kantian) assumption that such rights follow from the exercise of jurisdiction by a legitimate state. As Stilz puts it, 'only states can claim territorial jurisdiction because only they can promulgate and enforce a unitary, public, and objective criterion of rights, especially property rights, that binds everyone in a given area, thereby overcoming the problems of unilateral interpretation and assurance'. ${ }^{40}$ It might seem to follow, therefore, that non-state-based groups cannot claim rights of self-determination, because they cannot assert the relevant territorial rights that would be necessary to practise it. The Quebecois, for example, cannot demand selfdetermination for the province of Quebec, since Canada's current exercise of jurisdiction gives it territorial rights in that province. The only circumstance in which their demand could succeed would be if Canada decided to relinquish those rights, in which case Quebec would become terra nullius, and its occupants would then have the right, on Kantian principles, to create a new state in that place.

The issue here is whether jurisdiction alone is sufficient to confer rights to territory. To avoid the annexation problem, Stilz requires that for a state justifiably to wield such rights, it must represent the people who (faultlessly) occupy the territory. But in the cases we are considering, the question is whether the existing state does adequately represent all of the occupants, given that part of its territory contains people most of whom, let us suppose, aspire to be independent. Imagine a referendum is held and a substantial majority in that area vote for independence. Of course the state may still be able to claim that it represents (the majority of) all the people under its jurisdiction. But there seems to be an alternative arrangement involving secession that is more representative still. Can the present state continue to assert its territorial rights under these circumstances? It does not seem that a 
purely historical claim is sufficient here: the fact that a state has exercised jurisdiction over time as the representative of the occupants does not entail that its rights over the territory must extend indefinitely into the future. On the version of neo-Kantian theory we are now considering, the territorial claim has to be redeemed continuously. One can see this by thinking about what happens when a revolution occurs. The ancien regime cannot claim ongoing territorial rights on the grounds that it was once the legitimate representative of the people occupying the territory. Those rights belong to the regime that now represents the people, provided that it discharges the appropriate functions. In a similar way, if within a particular department of the state the inhabitants cease to regard it as the legitimate representative of their interests, then its rights over that department are put in question. Whether outright secession is the appropriate response is another matter. The key point here is that self-determination demands by non-state groups cannot be blocked simply by appeal to territorial rights, since whether the existing state has those rights, normatively speaking, is going to be one of the contested issues.

In her more recent work, Stilz has modified her position in such a way that the door to secessionist claims is opened more widely (but still, she hopes, without the position collapsing into voluntarism). Abandoning the view that a people with a right to selfdetermination must have been 'brought into being' by a state, she now argues that 'a state's claim to rule a particular population is derived, not just from its protection of human rights, but also from the willing affirmation of a politically cooperative relationship by a wide majority of participants'. ${ }^{41}$ It follows that when a minority group no longer affirm the existing scheme of political cooperation, they have a pro tanto case to secede and establish their own scheme. What does it mean to 'affirm' a political relationship? According to Stilz, 
the first requirement is that one should act voluntarily to sustain it by, for example, obeying the law, paying taxes and co-operating with public officials. But this is only the objective side of affirmation. There is also a subjective side, which is a matter of how the participant regards the authority to which she is subject. ${ }^{42}$ And here affirmation can fail, even in cases where the state is doing a good job of protecting everyone's human rights. One such case in which a 'warranted failure of subjective legitimacy' occurs is where past oppression has left behind 'a legacy of alienation': this is how Stilz explains why the Irish had a valid claim for independence in the early $20^{\text {th }}$ century. But there can also be a 'simple failure of subjective affirmation' where the alienated group comes to have different priorities from the majority over 'fundamental issues about how to organize political life'. This, she now thinks, may be true in the case of Scotland or Quebec, where there is 'no significant legacy of historical oppression', but nonetheless a case for independence can be made as a result of the 'distinctive political priorities' of the citizens of those regions. ${ }^{43}$

The problem here, for anyone who aspires to remain an heir to Kant, is that by introducing subjective affirmation as a condition for self-determination, one appears to abandon the idea that each person is under an obligation both to enter the civil condition and to uphold any existing state that embodies it. Stilz responds to this problem by arguing that the obligation does not involve submitting to any coercive authority in particular: 'while the alienated have a duty of justice to submit to coercion by some reasonably just coercer, they may have no equivalent duty to submit to this particular coercer. If another institution would be equally consistent with others' external freedom, and more reflective of their values and priorities, why can't they institute it instead?'. ${ }^{44}$ But this really is a major departure from Kant who, to recall, argued that it was permissible to compel people with 
whom one unavoidably interacted to submit to the authority of the state. Giving people the choice of which coercive authority to submit to descends into voluntarism and becomes a recipe for political fragmentation, since any group - not just the colonized, or minority nations like the Scots and the Quebecois - that was territorially concentrated could then declare and act on their collective preference to create a new political unit. The line that separates Kantian theories of legitimacy from consent-based theories of Lockean provenance has been crossed. ${ }^{45}$

\section{Self-Determination and Political Identity}

Let us take stock of the argument so far. The essential dilemma faced by neo-Kantian theories of self-determination is the following. The Kantian theory of the state, taken by itself, has nothing determinate to say about where the territorial boundaries of the state should be placed. Once the historical process of boundary-setting has taken place, however, 'peoples' are formed on a territorial basis, and it is these territorially-created groups that are awarded rights of self-determination. But if a neo-Kantian wants to follows Kant's own lead in his later writings, when he condemns both colonialism and state annexation, the theory has to say something more about what makes a state legitimate, beyond its instrumental role in providing the conditions of external freedom - since a benign colonial regime (or an annexing state) might well do that. We have examined two possible ways forward. One involves ramping up the standard of distributive justice required for legitimacy; but this falls foul of the problem of value disagreement that the Kantian state exists to overcome. The other involves strengthening the requirement that the state should represent the people that it governs; but the danger here is that this leads us down a slippery slope towards voluntarism, where any group that becomes disaffected 
and is no longer able to 'affirm' the state in its current form has the right to break away and form a new state. Following the second path does indeed explain why it was legitimate for subject peoples to resist colonialism and annexation, but at the cost of opening the door much more widely to secession, and putting the theory's Kantian credentials in doubt.

What the neo-Kantians I have been discussing seek to avoid is any appeal to political identity as a way of determining which self-determination claims are valid and which are not. In her earlier work, Stilz appealed to 'political co-operation' as a substitute for identity: what held peoples together was the fact of having sustained a co-operative political relationship over time. The problem with this approach was that it biased the outcome too heavily in favour of peoples who already possessed a state, and had difficulty handling cases in which a subject people has little choice other than to collaborate with their rulers. The missing element in this picture does seem precisely to be political identity: a group can have its own political identity even while it is being denied the opportunity to engage in political cooperation internally, and it is the fact of separate political identities that is needed to explain what is wrong about colonialism and annexation, even in cases where the colonised have been given political rights. What justified the Irish claim for self-government was the presence of a widely shared Irish, and explicitly anti-British, political identity, notwithstanding the shared system of political representation that existed in the years before 1922.

The question then turns on whether it is possible to conceptualise political identity in a way that avoids any reference to nationality. One suggestion is that political identity can be cashed out in terms of the distinctive political values that the identity group upholds. As we saw, when Stilz asks why peoples such as the Scots and the Quebecois might have valid 
claims to self-determination, she suggests that these groups have 'political priorities' that distinguish them from the dominant majority in the states they now form part of. But this suggestion runs into two kinds of problem. One is that the claim about 'distinctive political values' is difficult to sustain empirically in most cases where we might think that a prima facie case for secession exists. How likely is it, for example, that the political values of Norwegians and Swedes were significantly different when they chose to separate in 1905 ? Or to take the more recent case of the Scots, studies have shown that 'Scottish political values' are very little different from those held in large parts of England, especially in the North, and that even such small differences as exist may be reducible to variations in class composition. ${ }^{46}$ The other problem is that although political values may be one component of political identity, they are by no means the only component, nor necessarily the one that is most psychologically powerful as a source of unity within the group. The values that are commonly cited as sources of political identity in liberal democracies - freedom, justice, the rule of law, democracy itself - are not only shared across many societies but are also too cerebral to create a strong sense of commitment to a particular group. The other components of identity will typically be language, a shared history, social practices, symbols, sometimes a religion - all those things that together make up a 'way of life'. Identities, in other words, are cultural as well as political, and what is missing when self-determination is denied is the opportunity to express and protect these identities by political means.

This, of course, is just another way of saying that national identity is the source of selfdetermination claims in the real world, both in the case of groups that are already selfdetermining (e.g. by having their own state) and in the case of groups that wish to be. Now neo-Kantians do not deny that the groups they regard as having valid claims to self- 
determination are in practice likely to be nations, in the cultural sense; they concede that the results of applying neo-Kantian theory will in many instances coincide with those of nationalist theory. ${ }^{47}$ So where do the two theories of self-determination diverge? NeoKantians deny that there is any intrinsic value either to having a national identity or to expressing it politically. For them, the justification of self-determination cannot be that it allows a nation to promote its own distinctive cultural values and objectives. But might they nonetheless concede that national identity has instrumental value in providing one of the conditions required for successful political co-operation? There is now a large body of empirical literature exploring the connection between collective identities and social and political trust. ${ }^{48}$ Although the exact nature of the connection is debated, there is a consensus that in large, diverse societies, sharing a national identity is one of the factors that encourages people to trust one another as individuals, and also to trust the institutions that govern them. Since trust in turn is a prerequisite for democracy, and neo-Kantians regard democratic institutions as the best way for a people to achieve of self-determination, it seems that they should at least be ready to accept the instrumental case in favour of nationality as the basis on which territorial units are formed.

Why might they be reluctant to make this concessive move? One reason is a concern that national identities are never fully inclusive of all those who inhabit the territory in question. Thus when states, or subunits within states, are formed on a national basis, a line will often be drawn between citizens who by virtue of their descent or cultural identity qualify as part of the core group, and those who are more peripheral (think of the expressions that have evolved in different societies to mark out the core group - 'true Brit', 'Français de souche', 
'Québécois pur laine', etc.). Those on the margins will be unable to see themselves as equal participants in a collective project of self-determination.

As I noted earlier, this is one of the main challenges that nationalist theories of selfdetermination have to overcome: how can national identities remain sufficiently determinate that they can perform the unifying role that the instrumental argument allots them while becoming sufficiently inclusive to resonate with cultural minorities, immigrants and other groups beyond the historic 'core'? I cannot here examine what resources nationalist theories have to meet this challenge. I want instead to focus on a second reason why neo-Kantians may want to resist making any concessions to nationalism. This stems from a reading of Kant according to which the political problem must be solved by reason alone: the imperative to form political communities is a purely rational imperative, so to allow their boundaries to be established according to the sentiments and emotions that nationhood evokes (the 'mystic chords of memory' and so forth) would be to contradict that imperative. This comes through most clearly in Waldron's assertion that:

the point of setting up a political community is to preclude or resolve conflict, by providing a legal framework in which interests can be pursued, disputes resolved, justice done, actions coordinated, and public goods secured. If anything, this conception of political community rests upon an assumption of mutual antipathy or least diffidence; it is more like a Hobbesian conception. The idea is that we form political community with those with whom [we] are likely to fight, rather than with those whom we already like and who are, in their identity, already like us. ${ }^{49}$

And Waldron makes it clear that he takes from Kant the idea that this is a 'morally necessary' task; there is a 'moral imperative to establish a civil constitution and a system of 
law' $^{50}$ But if we allow political communities to be formed on the basis of cultural affiliation, among people who are already disposed to trust one another, then this necessary task has been evaded.

But need Kantians take such an austere line? Kant himself recognized that morally desirable ends can sometimes only achieved indirectly, by relying on motives that are not themselves moral. A good example is his argument that once 'the spirit of trade' has seized states, they will be motivated by the power of money to form alliances to promote peace. In this way, he says, 'nature guarantees perpetual peace through the mechanism of human inclinations itself' ${ }^{51}$ As we have already seen, he also credits nature with wisely dividing people by language and religion, thereby preventing the emergence of a potentially despotic world state. We might call this Kant's version of the Cunning of Reason: rational ends are achieved in unforeseen ways by human motivations that are not themselves moral. It introduces a noteworthy element of realism into his political thought. Why, then, should neo-Kantians insist that self-determining political communities must be formed on a territorial basis even among people who experience 'mutual antipathy'? ${ }^{52}$ Why not recruit the natural tendency of human beings to form themselves into culturally-based identity groups as a means to generate the trust that enables states, especially democratic states, to function well? A realistic theory of self-determination should not turn its back on the findings of political sociology. By denying themselves this resource, contemporary neo-Kantians appear paradoxically to be plus royalistes que le roi.

\footnotetext{
${ }^{1}$ This article originated as a paper presented to the Wallenberg Symposium on 'Popular sovereignty and territory: the challenge of democracy in the age of globalization',
} 
Stockholm, January 8-9, 2013, and later to the Centre for the Study of Social Justice, Oxford University, October 13, 2014. I am grateful to both audiences for their critical comments, and also to four reviewers for this journal for their help in revising the paper for publication. I should also like to thank Anna Stilz for allowing me to read two of her recent papers before they were published.

${ }^{2}$ I do not assume that jurisdiction must be exclusive, since there can e.g. be federal arrangements in which regions or provinces are given partial jurisdiction over portions of a state's territory, but the point is that here too jurisdiction is always over a bounded geographical area.

${ }^{3}$ Colonialism can take a number of different forms, and there are specific wrongs associated with each of them, but alien rule is one of its pervasive features that raises questions of justification. For a recent discussion focussing exclusively on this feature, see Lea Ypi, 'What's Wrong with Colonialism', Philosophy and Public Affairs, 41:2 (2013), pp. 158-91.

${ }^{4}$ I shall focus in particular on Jeremy Waldron and Anna Stilz. See Jeremy Waldron, 'Two Conceptions of Self-Determination' in Samantha Besson and John Tasioulas (eds.), The Philosophy of International Law (Oxford: Oxford University Press, 2010), pp. 397-413; Anna Stilz, 'Why do States have Territorial Rights?' International Theory, 1:2 (2009), pp. 185-213; Anna Stilz, 'Nations, States, and Territory', Ethics, 121:3 (2011), pp. 572-601; Anna Stilz, 'Decolonization and Self-Determination', Social Philosophy and Policy, 32:1 (2015), pp. 1-24; Anna Stilz, 'The Value of Self-Determination'. Lea Ypi has also extended Kant's theory of the state in new directions in 'What's Wrong with Colonialism' and in Lea Ypi, 'A Permissive Theory of Territorial Rights', European Journal of Philosophy, 22:2 (2014), pp. 288-312, but her focus is not on what constitutes a 'people' for purposes of self-determination - she is agnostic about that - but on the duty falling on any political community to enter into 'rightful' political relations with other communities. 
${ }^{5}$ David Miller, On Nationality (Oxford: Clarendon Press, 1995), chs. 2 and 4; David Miller, Citizenship and National Identity (Cambridge: Polity Press, 2000), chs. 7 and 8; David Miller, 'Debatable Lands', International Theory, 6:1 (2014), 104-21.

${ }^{6}$ I draw here on my analysis in David Miller, 'Property and Territory: Locke, Kant, and Steiner', Journal of Political Philosophy, 19:1 (2011), 90-109. For more detailed accounts of Kant's theory of state, see for example, Jeremy Waldron, 'Kant's Theory of the State' in Immanuel Kant, Toward Perpetual Peace and Other Writings on Politics, Peace, and History, ed. Pauline Kleingeld (New Haven and London: Yale University Press, 2006), pp. 179-200; Arthur Ripstein, Force and Freedom: Kant's Legal and Political Philosophy (Cambridge, MA: Harvard University Press, 2009), chs. 6-7; Katrin Flikschuh, 'Kant's Sovereignty Dilemma: A Contemporary Analysis', Journal of Political Philosophy, 18:4 (2010), pp. 469-83.

${ }^{7}$ Immanuel Kant, The Metaphysics of Morals, trans. Mary Gregor (Cambridge: Cambridge University Press, 1996), Part I, § 44, p. 90.

${ }^{8}$ I mean that there is no place for actual consent, whether express or tacit, in Kant's story. Hypothetical consent is another matter, and Kant does sometimes (see e.g. Kant, Metaphysics of Morals, §52, pp. 111-12) speak of the state embodying an 'original contract' while insisting that its actual origins are likely to have involved the use of coercion against 'uncivilised men'.

${ }^{9}$ Kant, Metaphysics of Morals, § 8, p. 45.

${ }^{10}$ Waldron, 'Two Conceptions of Self-Determination', p. 406.

${ }^{11}$ For contrasting views, see Flikschuh, 'Kant's Sovereignty Dilemma: A Contemporary Analysis', and Ypi, 'A Permissive Theory of Territorial Rights'. 
${ }^{12}$ See Kant, Metaphysics of Morals, §61, pp. 119-20; Immanuel Kant, Perpetual Peace: a Philosophical Sketch in Hans Reiss (ed.),Kant's Political Writings (Cambridge: Cambridge University Press, 1971), pp. 102-5. For a thorough discussion and an attempt to remove Kant's ambiguities, see Pauline Kleingeld, Kant and Cosmopolitanism: The Philosophical Idea of World Citizenship (Cambridge: Cambridge University Press, 2012), ch. 2.

${ }^{13}$ Kant, Perpetual Peace, p. 114.

${ }^{14}$ Kant, Perpetual Peace, p. 133.

${ }^{15}$ See Kant, Perpetual Peace, pp. 113-14. For evidence that Kant believed in national character, see his discussion of the characters of various European nations in Immanuel Kant, Anthropology from a Pragmatic Point of View in Immanuel Kant, Anthropology, History, and Education, ed. Gunter Zoller and Robert Louden (Cambridge: Cambridge University Press, 2007), pp. 407-15.

${ }^{16}$ For Kant's radical change of heart over the moral acceptability of colonialism, see Pauline Kleingeld, 'Kant's Second Thoughts on Colonialism' in Katrin Flikschuh and Lea Ypi (eds.), Kant and Colonialism: historical and critical perspectives (Oxford: Oxford University Press, 2014), pp. 43-67.

${ }^{17}$ See Kant, Perpetual Peace, pp. 106-7.

${ }^{18}$ See Kant, Metaphysics of Morals, §58, pp. 117-18.

${ }^{19}$ For an attempt to clarify Kant's thinking here, see Arthur Ripstein, 'Kant's Juridical Theory of Colonialism' in Flikschuh and Ypi, Kant and Colonialism, pp. 145-69. Ripstein summarises his reading in the claim that a colonised people 'is not fully a moral person because it is entirely passive in its relations to others' (p. 162). I examine this idea of 'moral personality' below. 
${ }^{20}$ Kant, Perpetual Peace, p. 94.

${ }^{21}$ Kant, Anthropology, p. 408.

${ }^{22}$ Waldron, 'Two Conceptions of Self-Determination', p. 407.

${ }^{23}$ Might the argument be made that the Mozambicans possessed a legitimate state at the time before the Portuguese arrived, so the act of colonization was never permissible in the first place, and that explains its wrongness? But this solution faces two difficulties. One is that we can't be sure, in the case of actual colonial regimes, that there was a legitimate political authority covering the relevant area before colonization occurred. Perhaps there were just somewhat disorganized local communities, or rule by the satraps of a distant land empire. The other difficulty is that the history of virtually every state will at some point include a morally dubious act of conquest, so any realistic version of Kantianism cannot insist that for a state to be legitimate, it must have an immaculate pedigree.

${ }^{24}$ I assume here, perhaps anachronistically, that one can speak of 'Palestinians' in the period before the First World War.

${ }^{25}$ Both Waldron and Stilz argue explicitly against conflating self-determination and democracy, and allow that political self-determination may be consistent with some nondemocratic forms of government. See Waldron, 'Two Conceptions of Self-Determination', p. 408; Stilz, 'Why do States have Territorial Rights?' p. 209; Stilz, 'Nations, States, and Territory', p. 589.

${ }^{26}$ Separation by salt water cannot by itself be sufficient to destroy legitimacy, or we would have to conclude that Athens cannot legitimately govern Crete or Rhodes, or Madrid govern Lanzarote and Tenerife.

${ }^{27}$ Allen Buchanan, Justice, Legitimacy, and Self-Determination: Moral Foundations for International Law (Oxford: Oxford University Press, 2004), esp. ch. 8. 
${ }^{28}$ Buchanan, Justice, Legitimacy, and Self-Determination, pp. 353-59. I shall not discuss the critique of colonialism that locates its injustice in the usurpation of the colonized people's territorial rights. This critique may indeed be valid, but it is not available within neo-Kantian theory, since according to that theory territorial rights follow from rather than precede political jurisdiction - so a successful colonizing power will necessarily supersede the rights of the indigenous group by establishing jurisdiction. This point is made by Ypi, 'A Permissive Theory of Territorial Rights', pp. 300-301.

${ }^{29}$ The latter was included in his earlier discussion of the issues in Allen Buchanan, Secession: The Morality of Political Divorce from Fort Sumter to Lithuania and Quebec (Boulder, CO: Westview Press, 1991), pp. 38-45.

${ }^{30}$ Buchanan, Justice, Legitimacy, and Self-Determination, pp. 361-2.

${ }^{31}$ The republicans could of course point backwards towards what had happened half a century earlier. But it would need a further argument to show why a state should lose legitimacy now because of rights-violations that had occurred in some previous period. We don't, for example, think that the USA is not now a legitimate state because of its record on slavery, whatever view we hold about the need for apology and compensation.

${ }^{32}$ Waldron, 'Two Conceptions of Self-Determination', p. 410.

${ }^{33}$ For a full-blown voluntarist view, see Harry Beran, 'A Liberal Theory of Secession,' Political Studies 32:1 (1984), pp. 21-31; for a part-voluntarist 'hybrid' view, see Christopher Wellman, 'A Defense of Secession and Political Self-Determination' in Christopher Wellman, Liberal Rights and Responsibilities: Essays on Citizenship and Sovereignty (New York: Oxford University Press, 2014), pp. 98-118.

${ }^{34}$ Waldron, 'Two Conceptions of Self-Determination', p. 411. 
${ }^{35}$ Another author who appeals to 'respect' to explain the wrongness of even benign colonial rule is Christopher Wellman, $A$ Theory of Secession: the case for political self-determination (Cambridge: Cambridge University Press, 2005), pp. 55-57. According to Wellman, 'colonization is an affront to the colonized in the form of an attitude that says, "You cannot govern yourselves properly, and so we must govern you"'. But Wellman makes it explicit that the same argument applies to any group that wishes to secede and can show that it has the capacity to perform basic political functions, so this makes his position voluntarist in the way that, I claim, a neo-Kantian position cannot be. If denying any group self-determination means disrespecting its members, this leads to conclusions that no defender of Kant's theory of the state, including Waldron, could accept.

${ }^{36}$ Stilz, 'Why do States have Territorial Rights?' p. 209.

${ }^{37}$ Stilz also addresses the more difficult case where the state being annexed is not legitimate - she takes as her example the hypothetical case of Nazi Germany being annexed at the war's end by the US. To explain what would be wrong about this, she has to invoke a German 'people' as the holders of a residual right to territory independently from the German state, yet without lapsing into nationalism. See Stilz, 'Nations, States, and Territory', pp. 590-592, and for a critical discussion Margaret Moore, 'Which People and What Land? Territorial Right-holders and Attachment to Territory', International Theory, 6:1 (2014), pp. 121-40.

${ }^{38}$ In an attempt to justify the asymmetry, Stilz refers to the legitimate expectations of those who are part of the existing scheme that it should continue: see Stilz, 'Nations, States, and Territory', p. 594, n. 34. But although some weight must be given to such expectations, it cannot be decisive, since the same would also apply, for example, to citizens of colonial empires about to be deprived of their colonies.

${ }^{39}$ Waldron, 'Two Conceptions of Self-Determination', p. 409.

${ }^{40}$ Stilz, 'Nations, States, and Territory', p. 582. 
${ }^{41}$ Stilz, 'Decolonization and Self-Determination', p. 15.

${ }^{42}$ Stilz's position at this point in the argument might be better described as 'neo-Hegelian' than as 'neo-Kantian', as she recognizes herself: 'freedom additionally requires that individuals who sustain state institutions together experience this activity as an expression of themselves, not as something that they are coerced into performing by an alien power' (Stilz, 'Decolonization and Self-Determination', p. 12).

${ }^{43}$ Stilz, 'Decolonization and Self-Determination', pp. 20-21. I suggest below that there is little evidence to support these claims about distinct political priorities. Where political disagreement occurs, it is precisely over the question of whether these peoples should have states of their own, as opposed to devolved powers within a larger state, rather than about political values in general.

${ }^{44}$ Stilz, 'The Value of Self-Determination', p. 22.

${ }^{45}$ Stilz argues that her position remains distinct from consent-based theories of political legitimacy because it does not allow 'disaffected individuals' to refuse to participate in the state. Secession is only an option for groups that are not 'dispersed' but are 'territorially organized' and have 'broadly representative practices' (Stilz, 'Decolonization and SelfDetermination', p. 18). But defenders of consent theories also impose such requirements: for example Beran requires that the secessionist group should be 'territorially concentrated' and 'sufficiently large to assume the basic responsibilities of an independent state' (Beran, 'A Liberal Theory of Secession', p. 30) and Wellman, 'A Defense of Secession and Political Self-Determination' sets similar conditions. So in making this argument Stilz only distances herself from a version of consent theory so extreme that no-one actually holds it - except perhaps anarchists who might use it as a reductio of the very idea of state legitimacy.

${ }^{46}$ See, for example, John Curtice and Rachel Ormston, 'Is Scotland more Left-Wing than England?' British Social Attitudes, Special Report, 42 (2011), available at 
http://www.nuffieldfoundation.org/sites/default/files/files/scotcen-ssa-report.pdf; Ailsa Henderson, 'The Myth of Meritocratic Scotland: political cultures in the UK' in Philip Cowley and Robert Ford (eds.), Sex, Lies and the Ballot Box (London: Biteback Publishing, 2014). Henderson writes: 'Scots are not more meritocratic or communitarian than English or Welsh residents. Even where there are differences, they fade once you control for demographic characteristics such as social class. Scots feel differently about the UK, about how well it runs and how it should organize itself, but they don't necessarily feel differently about how a state in general should operate and what it should do for people.' (p. 104)

${ }^{47}$ According to Waldron, 'it is probably also true that the differences between the two approaches to self-determination are more ideal-typic than real. Each may approach the other in various regards, inasmuch as culture and identity may grow out of proximity'. (Waldron, 'Two Conceptions of Self-Determination', p. 412) Stilz also concedes that the groups picked out by her political co-operation criterion will often have cultural ties as well (and the examples she gives of 'peoples' who lack national cultures - Belgium, Canada and India - are certainly highly contestable); see Stilz, 'Decolonization and Self-Determination', p. 19.

${ }^{48}$ See, for example, Robert Putnam, 'E Pluribus Unum: Diversity and community in the twenty-first Century', Scandinavian Political Studies, 30:2 (2007), pp. 137-174; Richard Johnston, Keith Banting, Will Kymlicka, and Stuart Soroka, 'National Identity and Support for the Welfare State', Canadian Journal of Political Science 43:2 (2010), pp. 349-77; Linda Berg \& Mikael Hjerm 'National Identity and Political Trust', Perspectives on European Politics and Society, 11:4 (2010), pp. 390-407; Tim Reeskens and Matthew Wright, 'Nationalism and the Cohesive Society: A Multilevel Analysis of the Interplay Among Diversity, National Identity, and Social Capital Across 27 European Societies', Comparative Political Studies, 46:2 (2013), pp. 153-181.

${ }^{49}$ Waldron, 'Two Conceptions of Self-Determination', p. 409.

${ }^{50}$ Waldron, 'Two Conceptions of Self-Determination', p. 412. 
${ }^{51}$ Kant, Perpetual Peace, p. 114.

${ }^{52}$ This charge applies more directly to Waldron than to Stilz, since Stilz, as we have seen, believes that the peoples who have a right of self-determination are those with an established history of political co-operation - evidence, presumably, that they have been able to keep their mutual antipathies in check. 